\title{
Yönetim Kuramları Bakımından Günümüz Okul Yöneticilerinin Yönetim Anlayışları
}

\author{
Ebru ÖZDEN*
}

\author{
Mehmet Ali HAMEDOĞLU*
}

Öz

Araştırmada, okul müdürlerinin yönetim teorileri bakımından hangi kuşak (Baby Boomers, $\mathrm{X}$ ve $\mathrm{Y}$ Kuşağı) alışkanlıklarını daha çok yansıttığının belirlenmesi amaçlanmıştır. Okul yönetiminin kuşaklar açısından ilk kez değerlendirileceği bu araştırmada; Sakarya'nın ilçelerinde ilk ve orta dereceli okullarda görev yapan 438 öğretmenle 60 yöneticiye Özden (2013) tarafından geliştirilen “Yönetici Tutumlarının Kuşaklara Göre Değerlendirilmesi" anketi uygulanmıştır. Araştırma tarama modeli ile gerçekleştirilmiştir. Verilerin analizinde tanımlayıcı istatistiksel metotların (frekans, yüzde) yanında bağımsız örneklem t-testi ve tek yönlü ANOVA analizi kullanılmıştır. P değerinin $\leq .05$ olduğu durumlarda ilişki anlamlı olarak yorumlanmıştır. Sonuçta; okul yöneticileri kendi yönetimsel davranışlarını Y Kuşağı'na, öğretmenlerse yöneticilerin yönetimsel davranışlarını çoğunlukla X Kuşağı'na, bazen de Y Kuşağı'na yakın bulmuşlardır. Bu da yöneticilerin kendilerini çoğunlukla çağdaş ve insana yönelik bulurken, öğretmenlerin her zaman böyle düşünmediklerini göstermiştir. Erkek öğretmenler yöneticilerin davranışlarını çoğunlukla Y Kuşağı'na yakın oylayarak onları kadın öğretmenlere göre daha çağdaş ve insana yönelik bulmuşlardır. Yöneticinin yaş değeri yükseldikçe öğretmenler tarafından klasik ve otoriter bir yönetici olarak algılandığı saptanmıştır. Yaşı ne olursa olsun eğitim seviyesi yükselen bir yönetici daha çağdaş ve insana yönelik olarak algılanmıştır. Baby Boomers ve X Kuşağında en fazla oylanan yöneticilerin memleketi Karadeniz Bölgesi, Y kuşağında en fazla oylanan yöneticilerin memleketi ise İç Anadolu ve Doğu Anadolu Bölgesi olmuştur.

Anahtar Kelimeler: Kuşaklar, Okul Yöneticisi, Baby Boomers Kuşağı, X Kuşağı, Y Kuşağ1

\section{Today's School Manager's Management Comprehension Examined in Point of Management Theories}

\begin{abstract}
In this study, it is aimed to determine which generation (Baby Boomers, X Generation and Y Generation) habits of school managers reflect more in the point of management comprehension. The study that evaluating the first time The Manager's Attitude Scale According to The Generations which is developed by Özden was used to 438 teachers and 60 managers chosen by probability based sampling from approximately 6500 teacher group. This study was carried out with scan model. In the data analysis, descriptive statistical methods (frequency, percentage) were used as well as
\end{abstract}

* Sakarya Üniversitesi, Eğitim Yönetimi ve Denetimi Programı Yüksek Lisans Öğrencisi,ozden.ebru@hotmail.com

** Yrd. Doç. Dr., Sakarya Üniversitesi Eğitim Fakültesi, Eğitim Bilimleri Bölümü, mhamed@sakarya.edu.tr 
independent samples t-test, one-way ANOVA. The relation was commentated as meaningful in situation that $\mathrm{P}$ value is $<.05$. As a result, the school managers find their management attitudes close to the $Y$ Generation, also teachers see manager's attitudes close to the $X$ Generation, sometimes $Y$ Generation. This shows that managers find themselves usually contemporary and intended for person, but the teachers don't think like this every time. Male teachers usually voted their manager's attitudes close to Y Generation and found them more contemporary and intended from human than the female teachers found. It is determined that the managers was seen classic and authoritarian by the teachers, as their age is rising. No matter what the age of the manager whose education level is increasing was seen as more contemporary and intended for human. The most voted managers as Baby Boomers and $X$ generation are from Black Sea Region, the most voted managers as Y Generation are from Inner Anatolia Region and East Anatolia Region.

Keywords: Science and Technology course, Project Based Learning Method, Teacher Opinions, Parent Opinions.

\section{GİRIŞ̧}

Kuşak teorisi; belirli zaman aralığında doğan bireylerin benzer değer yargılarını taşımalarını, benzer davranışlar sergilemelerini ve benzer yaşam biçimlerini tercih etmelerini aynı çağda doğmuş olmalarıyla açıklamıştır (Ayhün, 2013; Türk Dil Kurumu, 2005).

\subsection{Kuşaklar, Kuşakların Yönetim Algısı ve Okul Yönetimi}

\subsubsection{Baby Boomers Kuşağ1}

İkinci dünya savaşından hemen sonraki yıllarda (1945-1965) doğanlar "Baby Boomers Kuşağ1" olarak isimlendirilmiştir (Ayhün, 2013). Soyut ve manevi kavramlara olan ilgileri ağır basan (Twenge, 2009) bu kuşağın toplam nüfus içerisindeki oranı 2000 yılı rakamları ile \%15,2'dir (Senbir, 2004). Çoğu lise eğitimini bile tamamlayamamıştır. Bu dönemde erken yaşta evlendirilen kadınların okur-yazarlık oranı düşüktür (Bezirci, 2012). Dolayısıyla bu kuşakta kadın çalışanların sayısı azdır. Kadın yönetici sayısı ise neredeyse yok gibidir.

Baby Boomers Kuşağı'nın yönetici pozisyonunda olduğu dönemde yönetime hâkim olan pozitivist yaklaşım insanın psiko-sosyal yönünü göz ardı etmiş ve onu tek boyutlu mekanik bir varlık olarak algılamıştır. Emeklere karşılık taahhüt edilen tek şey ücret olmuştur. Denetim sıkı kontrol sistemleri ile yapılmıştır. Yönetim yukarıdan aşağıya doğru modellenmiş, örgütte kaybedenler ve kazananlar olmuştur (Conger, 1998). Bu yaklaşımın problemli dört alanı itaat, denetim, sözleşme ve kısıtlama olarak belirlenmiştir (Saylı, 2008).

Baby Boomers Kuşağı'nın Okulu Modern okuldur. Modern okul yöneticisi yetkisini kimseyle paylaşmamış, gücünü kuralların işleyişini sürdürmek için kullanmıştır. Okul yöneticisi insana yönelik olmaktan çok, işe yöneliktir ve merkezi otoriteyi memnun etmek için çaba harcamıştır. Bu okulda bireysel çeşitlilik bir tehdit olarak algılanmış ve hâkim ideolojiye göre insan yetiştirmek hedeflenmiştir. Eğitim müfredata göre bilgi aktarmak olarak sınırlandırılmıştır (Arslanargun, 2007).

\subsubsection{Kuşağı}

X Kuşağı 1965-1977 yılları arasında doğan tam bir geçiş kuşağıdır (Senbir, 2004: 24). Bu kuşak 2008 yılı nüfus sayımına göre Türkiye nüfusunun \% 22,21'ini teşkil etmektedir (Yiğit, 2010). Üniversiteli çalışan sayısı artmış, kadınlar işgücüne katılmış ve sahip olunan çocuk sayısı azalmıştır (Mengi, 2009; Seçkin, 2000). Kariyer basamaklarını tırmanan kadınlar yönetim kadrolarında yer almaya başlamış, ancak sayıları erkek yöneticilerle denkleşmemiştir. Hızlı değişen piyasa şartlarının getirisi olarak iş dünyası bu dönemde hizmetiçi eğitimlerle tanışmıştır. Ancak bu kuşak çalışanı, eğitimlere katılmak için çok hevesli olmadı ve yararına da inanmadı (Sözer, 2014). 
Bu kuşakla birlikte yönetimde insan ön plana çıkmaya başlamış (Bayraktar, 2008), işler hiyerarşi ile değil proje takımları ile yürütülür olmuştur. Fiziki gücün yerini beyin gücü almaya başlamıştır. Bu değişimler yöneticinin konumunu işbirlikçi liderliğe doğru kaydırmıştır (Conger, 1998; Mengi, 2009; Miller, 2005). İlişkiler daha samimi bir hal almış, çalışanlar kendilerini savunabilmeye başlamıştır. Bu dönemde yönetime postmodern yaklaşım hâkim olmuştur. Postmodern yaklaşım; modern yaklaşımın dört sınırlı alanına, karşın dört geliştirici alan sunmaktadır. Bunlar; itaate karşı-öz disiplin, denetime karşı-destek, sözleşmeye karşı-güven, sınırlamaya karşı-yayılmadır (Saylı, 2008). Bu yer değiştirme sonucunda iş hayatında daha esnek yapılar oluşmuş, güç paylaşılmış, yönetici bir taraftan grubu yönetirken kendisi de grup tarafından yönlendirilmiştir (Alimoğlu, 2010; Saylı, 2008; Şişman, 1998).

X Kuşağının Okulu Postmodern okuldur. Bu okulda eşitlik ve çeşitlilik savunulmakta, öğretim programlarının belli bir ideoloji doğrultusunda düzenlenmesi eleştirilmektedir. Okulun temel amacı öğrenciyi sosyalleştirmek ve hayata hazırlamaktır. Yerelliğe ve çeşitliliğe vurgu yapılan okulda; yöneticinin görevi kaosu yönetmek, farklılıkları desteklemektir. Bunu yaparkende yöneticinin takip edebileceği ya da benzeyebileceğini standart bir model yoktur (Arslanargun, 2007; Şişman, 1998).

\subsubsection{Y Kuşağı}

1977-1994 yılları arasında doğmuş olanlar Y Kuşağı olarak adlandırılmaktadır. Bu kuşak 2000 yılı rakamları ile Türkiye nüfusunun \% 39,7'ini teşkil etmektedir (Senbir, 2004). En önemli özellikleri teknolojiyi iyi kullanmaları bu sayede bilgiye hızlıca ulaşmaları, kendilerine olan yüksek güvenleri ve özgürlüklerine düşkünlükleridir (URL1).
Y Kuşağı döneminde üniversite mezunlarının sayısında artış yaşanmıştır. Kadınların çalışma hayatındaki oranları yükselmiştir. X Kuşağı döneminde olduğu gibi Y Kuşağı döneminde de kadın yöneticilerin sayısında artış yaşanmış ancak yine erkek yöneticilerin sayısı ile bir denkleşme olmamıştır.

Y Kuşağı'nın iş dünyasına girmesiyle örgütler demokratik ilişkilere dayalı, öğrenmeye açık ve kendisini sürekli yenileyebilen, profesyonelce denetlenen, merkeziyetçilikten uzak yapılara dönüşmüştür. Geleneksel örgüt yapılarına göre yetki dağılımının daha işlevsel, rol tanımlarının daha genel ve esnek, liderliğin makam yetkisinden çok uzmanlık yeterliğine dayalı olduğu ve bağımsız çalışma yerine takım çalışmasının ön plana çıktığı bu çağdaş örgüt yapılarında, devamlılı̆̆ın sağlanması için insan kaynaklarının geliştirilmesi en önemli amaç haline gelmiştir (Gümüşeli, 2001). Bu kuşağın çalışanları ekstrem demokratik lider tipli yöneticileri tercih etmektedirler. Bu liderlik tipinde tüm kararlar astlara bırakılmıştır (Akdemir ve diğ. 2013). Zaten kararlardan en çok etkileneceklerinin farkında olan Y Kuşağı çalışanları, kararlarda söz sahibi olmayı net bir şekilde talep etmişlerdir (URL2). Özetle Y kuşağı ile birlikte geleneksel etkileşim, iletişim ve motivasyon araçlarının hepsi sorgulanmış ve bu kuşağının karakteristik özellik ve beklentilerinin ortaya çıkardığı örgüt yapıları ve yönetim biçimleri bugün çağdaş yönetim teknikleri adı altında toplanmıştır (Yelkikalan ve diğ. 2010).

Y Kuşağı'nın Okulu çağdaş okuldur. Çağdaş okulda örgüt takım çalışmasıyla iş görür. Okulun en önemli amacı öğrencililerin; istek, hız ve yeterlilikleri doğrultusunda bireysel gelişimlerinin sağlanmasıdır. Okul öğrencilerin bireysel gelişimini sağlarken, yönetici de bürosundan çıkarak, örgütün tek bir vücut halinde hareket etmesini sağlayacak organizasyonu yapmakla mükelleftir. Bu bağlamda çağdaş okul yönetici- 
ye, öğretim liderliği yapmak, öğretmenleri sinıfta ziyaret etmek, okul koridor ve dersliklerinde dolaşmak, okulda doğru zaman ve yerde görünmek, okulun genel gidişatını sürdürmek gibi kırtasiyecilikten arındırılmış, önemli misyonlar yüklemektedir (Balcı, 2000).

\subsection{Kuşakların Araştırmanın Değişkenleri ile İlgisi}

Araştırmanın incelediği değişkenlerden yaş, kuşak teorisine göre kişilerin hangi nesile dâhil olacağını; dolayısıyla hangi davranışları göstereceğini belirler. Kişiler yaş skalasıyla ait oldukları dönemin karakteristik davranış yapılarını iş dünyasına ve yönetim tarzlarına taş1maktadırlar. Okul yönetiminde görevli müdürlerin yaşlarının genelde 50 ve yukarı, çalışan öğretmenlerin ise daha genç olmasının görev değişkeni açısından; görüşlerde fark yaratacağı düşünülmektedir. Ancak kuşakların davranış özelliklerinin ortaya çıkması sadece yaşa bağlı değildir. Çünkü yaş kadar kuşaksal davranışların oluşumunda, imkânlara ulaşma seviyesi de etkendir. Ayhün (2013) yaptığı çalışmada değişen kuşaklarla birlikte Türkiye'deki bazı göstergeleri (nüfus, kişi başına düşen gelir, bir doktor başına düşen hasta sayısı, fakülte ve yüksekokul ve meslek yüksekokullarının mezun sayısı vb) değerlendirmiş ve Baby Boomers Kuşağı'ndan, Y Kuşağı'na doğru iyileşmelerin olduğunu görmüştür. Dolayısıyla yaşla birlikte imkânlara ulaşma seviyesi de kişinin davranışlarında belirleyicidir. Adıgüzel ve diğ. (2014) yaptıkları çalışmada Baby Boomers kuşağı için şu açıklama dile getirilmektedir: “Bu kuşağın sınırlarının belirlenmesinde ülkeler ve kültürler arası farklılıklar bulunmaktadır". Dolayısıyla Türkiye'nin farklı bölgelerinde aynı yaştaki insanlar farklı kuşakları yaşıyor olabilir. Araştırmada bu durum yetişilen kültür (memleket) değişkeni ile incelenecektir. Kadınların iş dünyasına geç girmesinin ve yönetim kadrolarının genelde erkeklerden oluşmasının; araştırmada kadın ve erkek katılımcıların görüşleri arasında fark yaratacağı düşünülmektedir.

\subsection{Kuşak Analizi ve Okul Yönetimi}

Farklı kuşaklar (Baby Boomers, X Kuşağı ve Y Kuşağı) iş dünyasında çalışmaya, yönetim kadrolarında görev almaya başladığında farklı çalışma stilleri ve yönetim anlayışları ortaya koymuşlardır. Günümüze yakın kuşaklar çağdaş teorilerle, daha eski kuşaklar ise klasik teorilerle uyuşan davranışlar göstermektedirler. Yönetim ve iş dünyasındaki gelişmeler önceki yıllarda daha yavaşken, değişen piyasa şartları ve rekabet gelişmeleri hızlandırmıştır. $\mathrm{Bu}$ da iş dünyasını doğru kararlar almak adına geleceği tahmin etmeye zorlamıştır. Kuşakların karakter analizi, yönetim algısı, yönetimle ilişkisi ve liderlik tarzı beklentilerinin saptanması şirketlerin yönetimi açısından büyük önem arz etmeye başlamıştır (Demirkaya ve diğ. 2015). Çünkü bu saptamalar gelecek tahmini için onlara dayanak olmuştur. Şirketler elde ettikleri bu verilerle kuşakları memnun edebilecek, insan kaynaklarından maksimum verimi sağlayacakları düzenlemelere gitmişlerdir. Örgütlerde birden fazla kuşağın bir arada çalıştığını düşünürsek, tüm kuşakları memnun edecek bir idari iklimi oluşturmak yöneticinin görevi olacaktır. Eğer bu uzlaşmacı ortam sağlayamazsa örgütte kuşak çatışması meydana gelecektir. Okullar kuşak çeşitliliğinin en fazla olduğu örgütlerdir. Okul müdürünün Baby Boomers, öğretmenlerin $X$ ve $Y$ Kuşağına mensup olduğu bir kurumda adı geçen nesillerin kırılma noktaları iyi yönetilmezse birbirleriyle çatışacaklardır. Örneğin örgüt adına kararları kendi kendine almaya alışmış bir Baby Boomers yöneticisi, $X$ ve $Y$ Kuşağı mensubu öğretmenlerin kararlara katılım taleplerine olumlu yanit veremezse bu, okulda probleme sebep olabilecektir. Literatüre göre okul yönetimi daha önce kuşak perspektifinden değerlendirilmemiştir. Okul yönetimini kuşaklar açısın- 
dan değerlendirilerek hem literatüre farklı bir bakış açısı kazandırılmak hem de okul yönetimine bu yönde veri sağlamak amaçlanmaktadır. Okul yönetimine sağlanan bu verilerle yönetimle ilgili düzenlemeler ve yenileşme hareketleri yapilabilecektir.

\section{4 İlgili Araştırmalar}

Literatürde, daha önce okul yöneticisinin yönetim anlayışının kuşaklar perspektifinden değerlendirildiği bir araştırmaya rastlanmamıştır. Ancak kuşaklar ile ilgili yapılan çalışmalar şöyledir; Yiğit (2010), 'X ve Y kuşaklarının örgütsel tutumlar açısından incelenmesi ve bir örnek olay', Toruntay (2011), 'Takım rolleri çalışması: X ve $Y$ Kuşağı üzerinde karşılaştırmalı bir araştırma', Keleş (2011) 'Y kuşağı çalışanlarının motivasyon profillerinin belirlenmesine yönelik bir araştırma', Bezirci (2012), 'Farkl1 kuşaklardaki hemşirelerin meslekten ve işten ayrılma niyetleri ile iş doyumlarının incelenmesi', Etlican (2012), 'X ve Y kuşaklarının online eğitim teknolojilerine karşı tutumlarının karşılaştırılması', Ayhün (2012), 'Kültürel değişimlerin örgütlerde kuşaklararası çatışmalara etkisinin incelenmesi: Akademisyenlere yönelik bir araştırma', Akdemir ve diğ. (2013) yaptığ1 'Y kuşağının kariyer algısı, kariyer değişimi ve liderlik tarzı beklentilerinin araştırılması', Keleş (2013), 'Girişimcilik eğiliminin kuşak farkına göre incelenmesi', Yüksekbilgili, (2013), Türk tipi y kuşağı, Taşlıyan ve diğ. (2014),'Y kuşağı iş yaşamından ne bekliyor', Demirkaya ve diğ. (2015), ‘ Kuşakların yönetim politikası beklentilerinin araştırılması'.

Bunlardan yönetimle yakından ilgili olan araştırmaların sonuçlarına bakacak olursak; Akdemir ve diğ. (2013) yaptıkları çalışmanın sonuçlarına göre $\mathrm{Y}$ Kuşağının beklentisi ekstrem demokratik tipli liderdir. Yüksekbilgili (2013) ve Taşliyan ve diğ. (2014) daha çok yurtdışı kaynaklı literatürlerden elde edilmiş kuşaklara ilişkin bilgilerin Türkiye için revize edilmesi gerektiğini belirtmişlerdir. Taşlıyan ve diğ. (2014) bunun yanında 'farklı gelişmişlik seviyelerine ait bölgelerde kuşakların yaş aralıkları da değişebilir' önermesinin araştırılmasını tavsiye etmektedir. Demirkaya ve diğ. (2015) yaş ve deneyimden bağımsız olarak tüm kuşakların yönetim algıları ve liderlik tarzı beklentilerinin literatürde Y kuşağı için saptanan özelliklerle benzerlik gösterdiğini ortaya koymuştur.

Proje Tabanlı Öğrenme yaklaşımının fen eğitiminde uygulanmasıyla ilgili çok sayıda çalışma olmasına rağmen; öğretmen ve veli görüşlerinin bir arada olduğu araştırmaların yetersiz sayıda olduğu gözlemlenmiştir. Dolayısıyla bu araştırmanın öğretmen ve veli görüşlerinin incelenecek olması, Fen ve Teknoloji dersinde kullanılan Proje Tabanlı Öğrenme yaklaşımının öğretmenleri ve velilerini nasıl etkilediğinin anlaşılmasına, Fen ve Teknoloji dersi öğretimi ile ilgili yapılacak çalışmalara katkısının olabileceği düşünülmektedir.

\section{YÖNTEM}

\subsection{Araştırmanın Amacı}

Araştırmanın amacı, katılımcıların okul yönetimine ilişkin algılarını incelemektir. Okul müdürlerinin yönetim tarzları incelenirken kuşakların karakteristik yönetim alışkanları ayırt edici olarak kullanılacaktır. Bu sayede okul müdürlerinim yönetim tarzlarının çağdaş ya da klasik anlayıştan hangisine yakın olduğu anlaşılabilecektir. Bu araştırmanın problemi; Sakarya'nın ilçelerinde, ilk ve orta dereceli okullarda görev yapan okul yöneticilerinin yönetim alışkanlıklarının, hangi kuşağın (Baby Boomers, X Kuşağı ve Y Kuşağ1) yönetim tarzına daha yakın olduğu şeklindedir.

Probleme bağlı alt problemler ise şöyle belirlenmiştir; Sakarya'nın ilçelerinde bulunan ilk ve orta dereceli okullarda görev yapan okul 
yöneticilerinin, yönetim profillerinin kuşaklara göre değerlendirilmesine ilişkin;

1) Yönetici ve öğretmen görüşleri arasında fark var midır?

2) Katılımcıların görüşleri arasında;

- Cinsiyete göre

- Yöneticinin yaşına göre

- Yöneticinin eğitim durumuna göre

- Yöneticinin yetiştiği alt kültüre (memleket) göre fark var mıdır?

Elde edilen veriler, yeni nesil öğretmenlerin istek ve beklentilerine ilişkin okul yönetiminin revize edilmesi, yönetim politikalarının belirlenmesi ve lider profilinin oluşturulması için kullanilabilecektir.

\subsection{Araştırma Modeli}

Araştırma ilişkisel tarama modelindedir. Konu ile ilgili olarak sunulan anketler resmi okullarda görev yapan öğretmenlere ve okul yöneticilerine uygulanmıştır. Bu uygulama sonucunda elde edilen veriler araştırmada kullanılmıştır. Araştırma Sakarya'nın ilçelerinde yer alan ilk ve orta dereceli devlet okullarında, 2013-2014 eğitim-öğretim yılı ve bu yılda görev yapan ve bu araştırmaya katılan 498 öğretmen ve yöneticinin görüşleri ile sınırlıdır. Bunun yanı sıra araştırma sadece, çalışma hayatında mevcut olan Baby Boomers, $X$ ve $Y$ Kuşaklarını kapsamaktadır.

\section{3 Örneklem Grubu}

Sakarya'nın ilçelerinde ilk ve orta dereceli okullarda görev yapan yaklaşık 6500 öğretmenden (2014-2015 Milli Eğitim İstatistikleri) oluşan evrenden basit ve tesadüfi örnekleme yöntemi ile seçilen 438 öğretmene ve 60 yöneticiye Özden (2013) tarafından geliştirilen Yönetici Tutumlarının Kuşaklara Göre Değerlendirilmesi anketi uygulanmıştır. Araştırmada örneklem büyüklüğünü hesaplamak için Yazı- cıoğlu ve Erdoğan (2004) tarafından oluşturulan kuramsal örneklem büyüklükleri çizelgesinden yararlanılmıştır.

\subsection{Veri Toplama Aracı}

$\mathrm{Bu}$ araştırmada; kuşakların yönetim algılarına ilişkin kritik noktalar; yurt içi ve yurtdışı literatür tarandıktan sonra ortaya çıkarılmış, uzman görüşlerine de başvurarak, bir anket formu hazırlanmıştır. Anketin hazırlanması sırasında kuşakların yönetim algılarını oluşturan davranışlarla ilgili çokça anket maddesi yazılmış, bunlardan bir havuz oluşturulmuştur. Daha sonra bu havuzdan üç kuşak için aynı anda ayırt edici olan anket maddeleri seçilmiştir. Sonunda öğretmen ve yöneticilerin görüşlerinin alındığı 46 maddelik Yönetici Tutumlarının Kuşaklara Göre Değerlendirilmesi anketi oluşturulmuştur. Anket sayesinde öğretmenler okul yöneticilerini, okul yöneticileri ise kendilerini değerlendirmişlerdir.

Ankette yer alan maddelere verilen cevapların aritmetik ortalamasının yorumu için, üçlü dereceleme ölçeğindeki seçeneklere 'katılıyorum' seçeneği için 3, 'kısmen katılıyorum' seçeneği için 2, 'katılmıyorum' seçeneği için 1 puan verilmiştir.

- 1 puan Baby Boomers davranış kalıplar1

- 2 puan X Kuşağı davranış kalıpları

- 3 puan Y Kuşağı davranış kalıpları olarak nitelendirilmiştir

Yönetici Tutumlarının Kuşaklara Göre Değerlendirilmesi anketi Cronbach's Alpha katsayısı .89 bulunmuştur ve geçerli düzeydedir.

\subsection{Verilerin Analizi}

Geçersiz anketler elendikten sonra, 498 adet anket sayesinde elde edilen veriler SPSS 22 (Statistical Package For Social Sciences) programına aktarılarak araştırmanın amaçları doğ- 
rultusunda hizmet edecek şekilde çözümlenmiştir. Verilerin analizinde tanımlayıcı istatistiksel metotların (frekans, yüzde) yanında bağımsız örneklem t-testi ve tek yönlü ANOVA analizi kullanılmıştır. $P$ değerinin $\leq .05$ olduğu durumlarda ilişki anlamlı olarak yorumlanmıştır.

\section{BULGULAR}

Anketlerden elde edilen verilere ilişkin bulgular, aşağıda tablo ve yorumları ile birlikte verilmiştir;

Tablo 1. Görev Değişkenine Göre Kuşakların Yüzde Dağılımları

\begin{tabular}{clcc}
\hline $\begin{array}{c}\text { Değişken } \\
\text { Görev }\end{array}$ & \multicolumn{1}{c}{ Kuşak } & $n$ & $\%$ \\
\hline \multirow{2}{*}{ Öğretmen } & B.B. & 3748 & 18.88 \\
& X kuşağ1 & 6919 & 34.85 \\
& Y kuşă̆1 & 9182 & 46.25 \\
& Toplam & 19849 & 100 \\
\hline \multirow{2}{*}{ Yönetici } & B.B. & 178 & 6.51 \\
& X kuşağ1 & 807 & 29.53 \\
& Y kuşağ1 & 1747 & 63.94 \\
\hline
\end{tabular}

Tablo 2. Görev Değişkeni Açısından Yöneticilerin Yönetim Alışkanlıkları

\begin{tabular}{|c|c|c|c|c|c|c|c|}
\hline Anket Maddeleri & & $n$ & $\overline{\mathrm{x}}$ & $S S$ & $S d$ & $t$ & $P$ \\
\hline \multirow[t]{2}{*}{ Görevi sorgulamadan yapma } & Öğretmen & 436 & 1.66 & .69 & 493 & 5.77 & $.000^{*}$ \\
\hline & Yönetici & 54 & 2.22 & .72 & & & \\
\hline \multirow[t]{2}{*}{ İş değiştirme riskini göze alma } & Öğretmen & 429 & 2.14 & .77 & 487 & 2.27 & $.023^{*}$ \\
\hline & Yönetici & 60 & 1.90 & .72 & & & \\
\hline \multirow[t]{2}{*}{ Bilgisayar teknolojisini benimseme } & Öğretmen & 431 & 2.32 & .73 & 489 & 4.47 & $.000^{*}$ \\
\hline & Yönetici & 60 & 2.76 & .46 & & & \\
\hline \multirow{2}{*}{$\begin{array}{l}\text { İş ve özel yaşam dengesi için çalışanları } \\
\text { destekleme }\end{array}$} & Öğretmen & 435 & 2.40 & .74 & 493 & 4.76 & $.000^{*}$ \\
\hline & Yönetici & 60 & 2.86 & .38 & & & \\
\hline \multirow[t]{2}{*}{ Takım çalışmasını destekleme } & Öğretmen & 486 & 2.40 & .86 & 494 & 4.03 & $.000^{*}$ \\
\hline & Yönetici & 60 & 2.86 & .50 & & & \\
\hline \multirow[t]{2}{*}{ Bireysel olarak ödüllendirme } & Öğretmen & 433 & 2.06 & .78 & 490 & 5.78 & $.000^{*}$ \\
\hline & Yönetici & 59 & 2.67 & .53 & & & \\
\hline \multirow[t]{2}{*}{ Çalışanlara ilham verme } & Öğretmen & 436 & 2.05 & .77 & 492 & 3.74 & $.000^{*}$ \\
\hline & Yönetici & 60 & 2.45 & .56 & & & \\
\hline \multirow[t]{2}{*}{ Sosyal ilişkilere önem verme } & Öğretmen & 435 & 2.42 & .73 & 493 & 3.53 & $.000^{*}$ \\
\hline & Yönetici & 60 & 2.76 & .42 & & & \\
\hline \multirow[t]{2}{*}{ Ulaşılabilir olma } & Öğretmen & 434 & 2.75 & .54 & 492 & 2.78 & $.006^{*}$ \\
\hline & Yönetici & 60 & 2.95 & .21 & & & \\
\hline \multirow[t]{2}{*}{ Öğretmenlere takdir ve teşekkürlerini iletme } & Öğretmen & 430 & 2.29 & .74 & 487 & 4.86 & $.000^{*}$ \\
\hline & Yönetici & 59 & 2.77 & .45 & & & \\
\hline \multirow[t]{2}{*}{ Fiziksel ortamla ilgili hazırlık ve düzenleme } & Öğretmen & 428 & 2.20 & .73 & 485 & 4.42 & $.000^{*}$ \\
\hline & Yönetici & 59 & 2.64 & .51 & & & \\
\hline \multirow{2}{*}{$\begin{array}{l}\text { Yeni ve farklı görüşler ortaya atan öğretmen- } \\
\text { leri destekleme }\end{array}$} & Öğretmen & 429 & 2.36 & .70 & 486 & 4.37 & $.000^{*}$ \\
\hline & Yönetici & 59 & 2.77 & .45 & & & \\
\hline
\end{tabular}




\begin{tabular}{|c|c|c|c|c|c|c|c|}
\hline \multirow[t]{2}{*}{ Eleştirilmekten hoşlanmama } & Öğretmen & 427 & 2.04 & .75 & 484 & 3.74 & $.000^{*}$ \\
\hline & Yönetici & 59 & 1,66 & .68 & & & \\
\hline \multirow[t]{2}{*}{ Kararlara katılımı sağlama } & Öğretmen & 430 & 2.30 & .69 & 487 & 4.89 & $.000^{*}$ \\
\hline & Yönetici & 59 & 2.76 & .42 & & & \\
\hline \multirow{2}{*}{$\begin{array}{l}\text { Çalışanlarının } \quad \text { toplantılarda } \\
\text { özgürce ifade etmelerini sağlama }\end{array}$} & Öğretmen & 427 & 2.36 & .72 & 483 & 5.68 & $.000^{*}$ \\
\hline & Yönetici & 58 & 2.91 & .28 & & & \\
\hline \multirow{2}{*}{$\begin{array}{l}\text { Toplantıda çalışanlarla alınan kararların uygu- } \\
\text { lanması }\end{array}$} & Öğretmen & 431 & 2.21 & .72 & 488 & 5.13 & $.000^{*}$ \\
\hline & Yönetici & 59 & 2.71 & .49 & & & \\
\hline \multirow[t]{2}{*}{ Çalışan için bir danışman olma } & Öğretmen & 430 & 2.09 & .75 & 487 & 5.79 & $.000^{*}$ \\
\hline & Yönetici & 59 & 2.67 & .47 & & & \\
\hline \multirow[t]{2}{*}{ Çalışanlarıyla omuz omuza olma } & Öğretmen & 427 & 2.12 & .75 & 484 & 6.67 & $.000^{*}$ \\
\hline & Yönetici & 59 & 2.79 & .44 & & & \\
\hline \multirow[t]{2}{*}{ Özel yaşam için danışman olma } & Öğretmen & 439 & 1.73 & .80 & 486 & 4.61 & $.000^{*}$ \\
\hline & Yönetici & 59 & 2.23 & .56 & & & \\
\hline \multirow[t]{2}{*}{ Eğitimi okul dışına taşıma } & Öğretmen & 430 & 2.22 & .76 & 487 & 4.91 & $.000^{*}$ \\
\hline & Yönetici & 59 & 2.72 & .44 & & & \\
\hline \multirow[t]{2}{*}{ Dostane tavirlı olma } & Öğretmen & 429 & 2.41 & .71 & 486 & 4.78 & $.000^{*}$ \\
\hline & Yönetici & 59 & 2.86 & .39 & & & \\
\hline \multirow{2}{*}{$\begin{array}{l}\text { Görevin neden ve nasıl yapılması gerektiğinin } \\
\text { açıklanması }\end{array}$} & Öğretmen & 430 & 2.36 & .69 & 487 & 4.82 & $.000^{*}$ \\
\hline & Yönetici & 59 & 2.81 & .43 & & & \\
\hline
\end{tabular}

Tablo 1'de görüldüğü gibi; Yöneticiler kendi yönetimsel davranışlarını kuvvetli bir puanla Y kuşağına yakın bulunmuşlardır. Öğretmenler yöneticilerin yönetimsel davranışlarını orta düzeyde bir puanla $Y$ kuşağına yakın bulmuşlardır. Kendisinde Baby Boomers Kuşağına özgü yönetimsel özelikleri gören yönetici oranı \% 6.51 iken, yöneticisinde Baby Boomers Kuşağına özgü yönetimsel özellikleri gören öğretmenlerin oranı \% 18.8 dir. Yukarıdaki sayısal veriler öğretmenlerin yöneticileri daha klasik ve otoriter tutumlu gördüklerini göstermektedir.
Tablo 2'de görüldüğ̈ü gibi; Anlamlı fark bulunan tüm maddelerde okul yöneticileri kendi davranışlarını genelde Y Kuşağına yakın bulmuşlardır. Yöneticilerin puanları $=1.90$ ile 2.95 arasında değişmektedir. Öğretmenler ise yöneticilerin davranışlarını bazen $Y$ Kuşağına çoğu zaman ise $X$ Kuşağına yakın bulmuşlardır. Öğretmenlerin yöneticilere verdikleri puanlar $=1.73$ ile 2.75 arasında değişmektedir. Bu da yöneticilerin kendilerini çağdaş ve insana yönelik bulurken öğretmenlerin her zaman böyle düşünmediklerini göstermektedir. Öğretmenlere göre yöneticilerin otoriter ve klasik tavırları vardir. 
Tablo 3. Cinsiyet Değişkenine Göre Kuşakların Yüzde Dağılımları

\begin{tabular}{|c|c|c|c|}
\hline $\begin{array}{l}\text { Değişken } \\
\text { Cinsiyet }\end{array}$ & Kuşak & $n$ & $\%$ \\
\hline \multirow{4}{*}{ Erkek } & B.B. & 1603 & 15.09 \\
\hline & X kuşağ & 3526 & 33.20 \\
\hline & Y kuşağ & 5492 & 51.71 \\
\hline & Toplam & 10621 & 100 \\
\hline \multirow{4}{*}{ Kadın } & B.B. & 2324 & 19.36 \\
\hline & X kuşağ 1 & 4211 & 35.07 \\
\hline & Y kuşağ1 & 5472 & 45.57 \\
\hline & Toplam & 12007 & 100 \\
\hline
\end{tabular}

Tablo 4. Cinsiyet Değişkeni Açısından Yöneticilerin Yönetim Alışkanlıkları

\begin{tabular}{llllllll}
\hline Anket Maddeleri & & $n$ & $\bar{x}$ & $S S$ & $S d$ & $t$ & $P$ \\
\hline Görevi sorgulamadan yapma & Kadın & 262 & 1.61 & .68 & 492 & 3.82 & $.000^{*}$ \\
& Erkek & 232 & 1.86 & .72 & & & \\
\hline Takım çalışmasını destekleme & Kadın & 263 & 2.38 & .88 & 493 & 2.21 & $.027^{*}$ \\
& Erkek & 232 & 2.55 & .78 & & & \\
\hline Eleştirilmekten hoşlanmama & Kadın & 258 & 2.10 & .76 & 483 & 3.41 & $.001^{*}$ \\
& Erkek & 227 & 1.87 & .73 & & & \\
\hline Okulda bürokrasinin azlığı & Kadın & 257 & 1.99 & .71 & 483 & 2.13 & $.033^{*}$ \\
& Erkek & 228 & 2.13 & .72 & & & \\
\hline Çalışanlarılyla omuz omuza olma & Kadın & 257 & 2.04 & .74 & 483 & 5.21 & $.000^{*}$ \\
& Erkek & 228 & 2.39 & .71 & & & \\
\hline Dostane tavırlı olma & Kadın & 259 & 2.34 & .72 & 485 & 4.14 & $.000^{*}$ \\
\hline
\end{tabular}

$\mathrm{p}<0.05 \quad{ }^{*}$ Anlamlı fark vardır.

Tablo 3'te görüldüğü gibi; erkek öğretmenler yöneticilerin davranışlarını çoğunlukla Y Kuşağı'na yakın oylayarak onları kadın öğretmenlere göre daha çağdaş ve insana yönelik bulmuşlardır.

Tablo 4'te görüldüğ̈ü gibi; bayan öğretmenlerin erkek öğretmenlere göre yöneticilerine daha düşük puanlar verdikleri görülmüştür. Kadın öğretmenlerin oyları $=1.61$ ile 2.38 arasında değişmektedir. Erkek öğretmenlerin oyları ise = 1.86 ile 2.60 arasında değişmektedir. Yönetim kadrolarının daha çok erkeklerden oluşması sebebi ile kadınların yönetimde temsil edilememesi böyle bir sonucu doğurmuş olabilir. Kadın öğretmenler ile yönetim arasında cinsiyet bakımından ortak payda olmayışı beklentilerin karşılanmamasına sebep olmuş, kadın öğretmenlerin yönetimi klasik ve otoriter alg1lamasına sebep olmuş olabilir. 
Tablo 5. Yöneticinin Yaşı Değişkenine Göre Kuşakların Yüzde Dağılımları

\begin{tabular}{cccc}
\hline $\begin{array}{c}\text { Değişken } \\
\text { Yöneticinin Yaşı }\end{array}$ & Kuşak & $n$ & $\%$ \\
\hline \multirow{3}{*}{$20-34$} & B.B. & 125 & 7.76 \\
& X kuşağı & 511 & 31.75 \\
& Y kuşağı & 973 & 60.47 \\
& Toplam & 1609 & 100 \\
\hline \multirow{3}{*}{$35-49$} & B.B. & 610 & 10.23 \\
& X kuşă̆1 & 1801 & 30.21 \\
& Y kuşağ & 3550 & 59.55 \\
& Toplam & 5961 & 100 \\
\hline \multirow{3}{*}{50 ve yukarı } & B.B. & 3191 & 21.25 \\
& X kuşağ & 5414 & 36.06 \\
& Y kuşağ & 6407 & 42.67 \\
& Toplam & 15012 & 100 \\
\hline
\end{tabular}

Tablo 5'te görüldüğü gibi; yöneticilerin yaşları 20-34 olan öğretmenler yöneticilerinin davranış özelikleri daha çok Y Kuşağını yakın bulmuşlardır. Aynı şekilde yöneticilerinin yaşları 35-49 olan öğretmenler de yöneticilerinin davranışlarını daha çok $\mathrm{Y}$ kuşağına yakın bulmuşlardır. Yöneticilerin yaşı ve 50 ve yukarı olan öğretmenlerin grubunda Baby Boomers kuşağı puanları diğer grupların Baby Boomers Kuşağ1 puanlarından yüksektir. Yöneticinin yaşı arttıkça Baby Boomers Kuşağı puanlarının arttı̆̆ı, Y kuşağı puanlarının azaldığı görülmüştür. Bu da gösteriyor ki yöneticilerin yaş skalası artıkça öğretmenler onları daha klasik ve otoriter bulunmaktadır.
Yaş değişkenine ilişkin Annova testinin sonuçlarına göre anket maddelerinin çoğunda yöneticilerinin yaşları 50 yaş ve üzerinde olan öğretmenlerin görüşleri ile yöneticilerinin yaşları 20-38 ve 39-50 arası olan öğretmenlerin görüşleri arasında anlamlı fark bulunmuştur. Bunun yanı sıra kendine güven seviyesi, farklılıkları yönetebilme, okuldaki zamanının çoğunu eğitim ortamlarında gözlem yaparak geçirme, yeni projeler üretme, facebook, twitter gibi sosyal ağları kullanma, giyim-kuşamını saygınlık unsuru olarak düşünme ve bu duruma dikkat etme maddelerinde; yöneticilerinin yaşı 50 yaş ve üzeri olan öğretmenlerin görüşleri ile yöneticilerinin yaşları 39-50 arası olan öğretmenlerin görüşleri arasında anlamlı fark bulunmuştur.

Tablo 6. Yöneticinin Eğitimi Değişkenine Göre Kuşakların Yüzde Dağılımları

\begin{tabular}{clcc}
\hline $\begin{array}{c}\text { Değişken } \\
\text { Yöneticinin Eğitimi }\end{array}$ & \multicolumn{1}{c}{ Kuşak } & $n$ & $\%$ \\
\hline \multirow{3}{*}{ Ön Lisans } & B.B. & 933 & 29.57 \\
& X kuşağ & 1137 & 36.03 \\
& Y kuşağ1 & 1085 & 34.38 \\
& Toplam & 3155 & 100 \\
\hline \multirow{2}{*}{ Lisans } & B.B. & 2634 & 16.84 \\
& X kuşağ 1 & 5572 & 35.63 \\
& Y kuşağ & 7432 & 47.52 \\
& Toplam & 15638 & 100 \\
\hline
\end{tabular}




\begin{tabular}{llcc}
\hline & B.B. & 359 & 9.47 \\
Yüksek Lisans-Doktora & X kuşă̆1 & 1017 & 26.84 \\
& Y kuşağ1 & 2413 & 63.68 \\
& Toplam & 3789 & 100 \\
\hline
\end{tabular}

Tablo 6'da görüldüğü gibi; yöneticilerin eğitim seviyesi artıkça öğretmenler tarafından davranışları Y Kuşağını daha yakın bulunmuştur. Bu da yöneticinin eğitim seviyesi yükseldiğinde öğretmenler tarafından daha çağdaş ve insana yönelik algılandığını göstermektedir.

Yöneticinin eğitimi değişkenine ilişkin Annova testinin sonuçlarına göre anket maddelerinin çoğunda yöneticileri ön lisans eğitimi almış öğretmenlerin görüşleri ile yöneticileri lisans eğitimi ve yüksek lisans eğitimi almış öğretmenlerin görüşleri arasında fark bulunmuştur. Aynı maddeler için maddeler için yöneticileri lisans eğitimi almış öğretmenlerin görüşleri ile yöneticileri yüksek lisans eğitimi almış öğretmenlerin görüşleri arasında fark bulunmuştur. İş ve özel yaşamı dengeleyebilmeleri için çalışanları destekleme, özel yaşam için yöneticinin danışman olması maddelerinde yöneticileri yüksek lisans eğitimi almış öğretmenlerin görüşleri ile yöneticileri ön lisans ve lisans eğitimi almış öğretmenlerin görüşleri arasında anlamlı fark bulunmuştur. Görevi sorgulamadan yapma maddesinde yöneticileri lisans eğitimi almış öğretmenlerin görüşleri ile yöneticileri yüksek lisans eğitimi almış öğretmenlerin görüşleri arasında anlamlı fark bulunmuştur.

Tablo 7. Yöneticinin Memleketi (Kültür) Değişkenine Göre Kuşakların Yüzde Dağılımları

\begin{tabular}{|c|c|c|c|}
\hline Değişken Memleket & Kuşak & $n$ & $\%$ \\
\hline \multirow{4}{*}{ Karadeniz } & B.B. & 986 & 20.62 \\
\hline & X kuşağ1 & 1901 & 39.76 \\
\hline & Y kuşağ1 & 1893 & 39.60 \\
\hline & Toplam & 4780 & 100 \\
\hline \multirow{4}{*}{ İç Anadolu } & B.B. & 528 & 14.48 \\
\hline & X kuşağ1 & 1028 & 28.20 \\
\hline & Y kuşağ & 2089 & 57.31 \\
\hline & Toplam & 3645 & 100 \\
\hline \multirow{4}{*}{ Doğu Anadolu } & B.B. & 1175 & 16.31 \\
\hline & X kuşağ 1 & 2213 & 30.71 \\
\hline & Y kuşağ & 3816 & 52.97 \\
\hline & Toplam & 7204 & 100 \\
\hline \multirow{4}{*}{ Marmara } & B.B. & 1077 & 17.33 \\
\hline & X kuşağ & 2348 & 37.78 \\
\hline & Y kuşağ1 & 2789 & 44.88 \\
\hline & Toplam & 6214 & 100 \\
\hline
\end{tabular}


Yöneticinin yetiştiği alt kültür (memleket) değişkenine ilişkin yapılan Anova testinin sonucuna göre; yöneticinin memleketi, öğretmen görüşleri arasında fark yaratmıştır. Tablo 7'de görüldüğü gibi memleketi İç Anadolu ve Doğu Anadolu olan yöneticilerin insana yönelik ve çağdaş yönetici olma puanları memleketleri diğer bölgelerden olan yöneticilerden yüksektir. Gruplar içerisinde memleketi Karadeniz Bölgesi olan yöneticilerin klasik ve otoriter algılanma yüzdeleri en fazladır.

\section{TARTIŞMA}

Araştırmanın sonuçlarını değerlendirecek olursak, okul yöneticilerinin kendi yönetimsel davranışlarını Y Kuşağı'na yakın bulduklarını söyleyebiliriz. Öğretmenlerse yöneticilerde çoğunlukla X Kuşağına, bazen de Y Kuşağına özgü davranış özelliklerini görmüşlerdir. Üstelik öğretmenlerin yöneticilere verdikleri Baby Boomers Kuşağı puanları daha yüksektir. Bu da yöneticilerin kendilerini çoğunlukla çağdaş ve insana yönelik bulurken, öğretmenlerin her zaman böyle düşünmediklerini göstermiştir. Benzer şekilde yöneticilerin değişim yönetimi yeterliliklerinin araştırıldığı ve yine görevin değişken olduğu bir araştırmada yöneticiler kendilerini çok düzeyinde yeterli görürken, öğretmenler yöneticilerinin bu konudaki yeterliliklerini orta düzeyde bulunmuşlardır (Argon ve Özçelik, 2008). Bu iki araştırmaya dayanarak okul yöneticilerinin kendilerine verdikleri puanların ve yeterlik değerlerinin yüksek olduğunu söyleyebiliriz. Eğitimde denetim sisteminin genellikle üssün assı değerlendirmesi üzerine kurulu olması, öğretmenlerin yönetimden beklentilerinin ne ölçüde karşılandığının ölçülmesini engellemektedir. Aslarından geri dönüt alamayan okul yöneticileri yaptıkları işe eleştirel bir gözle bakamamakta, görevlerini gereğince yerine getirdiklerini düşünmektedirler. Oysa duruma öğretmenlerin penceresinden bakınca, yönetimle ilgili bir takım eksiklerin görüldüğü ve memnuniyetsizliklerin olduğu anlaşılmaktadır.

Cinsiyet değişkenine ilişkin sonuçlarda ise kadın öğretmenlerin görüşleri ile erkek öğretmenlerin görüşleri arasında anlamlı fark bulunmuştur. Erkek öğretmenler yöneticilerin davranışlarını daha çok Y Kuşağına yakın oylayarak onları kadın öğretmenlere göre daha çağdaş ve insana yönelik bulmuşlardır. Kadın öğretmenlerin yönetimde hemcinsleri tarafından temsil edilmemesinin böyle bir farka sebep olduğu düşünülebilir. Kendileriyle benzer istek ve sıkıntı içerisinde olmayan erkek egemen bir yönetim, bayan öğretmenlerin beklentilerini istenen ölçüde karşılayamamış ve onların yönetimden yeterince destek görememe hissiyatına kapılmalarına sebep olmuş olabilir. Benzer şekilde Uzun'un (2008) yaptığı araştırmada erkek öğretmenler; okul yöneticilerine kadın öğretmenlerden daha yüksek anlayış gösterme liderlik puanları vermişler ve onları insana yönelik bulmuşlardır.

Araştırmaya göre okul yöneticisi; yaş değeri yükseldikçe öğretmenler tarafından klasik ve otoriter, yaş değeri düşdükçe çağdaş ve insana yönelik bir yönetici olarak algılanmaktadır. Kuşaklar değiştikçe yönetimde yeni trendler oluşmaktadır. Yaşı ilerledikçe, yönetici değişimlerin farkında olmazsa bu eğilimleri yakalama şansı düşmektedir. Örgüte gençler dâhil olmaya başladıkça beklentiler değişmekte, yönetim kendisini bu beklentilere göre revize edemezse çalışanlar nezdinde adeta modası geçmektedir. Araştırma göstermiştir ki yöneticilerin yaşları arttıkça çalışanların beklentilerinin karşılanma oranı düşmektedir. Benzer bir çalışmada Karadal ve Ünal (2003) 50 yaşın üzerindeki yöneticilerin itaat etme ve çekingenlik eğiliminin gençlere göre daha yüksek olduğu ve pasif/savunmacı bir yaklaşımı benimsediklerini belirtmişlerdir. Başka bir ifade ile, 50 yaşın üzerinde ki yöneticiler gençlere göre değişime ve yeniliğe karşı daha az ilgi göster- 
mekte; daha fazla bağımlı; inisiyatif kullanmaktan yoksun ve genellikle diğerlerinin onayına ihtiyaç duyar bir tavır sergilemektedirler. Kabacoff ve Stoffey (2001), Wah (1999), Hitt ve Tyler (1991) 45 yaş üstü yöneticilerin gerek 2534 gerekse 35-44 yaş grubundaki yöneticilere nazaran daha az yenilikçi hareketler gösterdiklerini açıklamışlardır (akt. Durmuş, 2002). Türetgen ve diğ. (2004) yaptıkları çalışmada 36-50 yaş grubu yöneticileri duygusal açıdan daha güçlü, yön vermede daha becerikli ve genel olarak liderlik vasıflarına daha çok sahip olarak bulmuşlardır.

Araştırmanın sonuçlarına göre eğitim yaşın yukarıda bahsedilen keskin etkisini yumuşatmış, yaşı ne olursa olsun eğitim seviyesi yükselen bir yönetici daha çağdaş ve insana yönelik olarak algılanmıştır. Yaşın kuşaklar arasında yarattığı farklılığı eğitim ortadan kaldırmaktadır. Yöneticinin eğitim seviyesi arttıkça çalışanların yönetimle ilgili memnuniyetleri de artmaktadır. Baran (2015) lisansüstü eğitimi almış okul yöneticilerinin "etkili bir örgüt yönetimi" ve "mesleğe hizmet" boyutlarında, lisansüstü eğitim almamış okul yöneticilerine kıyasla kendilerini daha yeterli gördüklerini açıklamıştır. Ayrıca Kuğuoğlu'nun (1997) yaptığı çalışmada; hem üsler hem de aslar eğitim yönetimi yüksek lisansı almış okul yöneticilerinin daha yüksek düzeyde yöneticilik davranışı sergilediğini belirtmişlerdir.

Yöneticinin yetiştiği kültür değişkenine göre, Baby Boomers ve X Kuşağında en fazla oylanan yöneticilerin memleketi Karadeniz Bölgesi, Y kuşağında en fazla oylanan yöneticilerin memleketi ise İç Anadolu ve Doğu Anadolu Bölgesi olmuştur. Yetişilen kültür bireylere farklı bakış açıları ve yaklaşımlar kazandırmaktadır. Farklı coğrafi bölgeler farklı sosyokültürel yapıları getirmekte bu da farklı kişilikleri oluşturmaktadır. Kişiler yetiştikleri kültürün güçlü ve zayıf yönlerini yönetim anlayışları ile birleştirmekte, farklı kültürlerden yetişmiş yöneticile- rin çalışanlarından aldıkları memnuniyet tepkileri de farklılık göstermektedir. Böylece yaş ile birlikte yetişilen kültür de kuşak farkını yaratan temel etkenlerden biri olarak karşımıza çıkmaktadır. Parlayan (2003) araştırmasında çekirdek aileden gelen yöneticilerin \%56' sının, orta büyüklükte bir aileden gelenlerin \%33'ünün, geniş aileden gelenlerin ise \%40' ının yöneticilik eğitimine gereksinim duyduklarını ortaya koymuştur. Aynı araştırmanın bir diğer sonucu ise demokratik aileden gelen yöneticilerin daha büyük oranda eğitime ihtiyaç duyduklarıdır. Bu sonuçlardan hareketle yöneticilerin seçimlerinin yetiştikleri kültürden ve sosyal çevreden etkilendiği çıkarımına varabiliriz. Kuşak mensuplarının karakter yapılarını tercihlerinin belirlediğini düşünürsek, kültür yöneticinin hangi kuşağa ait özelliği daha fazla göstereceğinde belirleyici olacaktır. Adıgüzel ve diğ. (2014) de yaş kadar imkânlara ulaşma seviyesinin de kişinin hangi kuşaksal davranışı göstereceğinde belirleyici olacağını söylemişlerdir. Dolayısıyla sosyoekonomik ve sosyokültürel yapı kuşak karakterlerinin ortaya çıkmasinda önemlidir.

Türkiye'de yaşayan 76.5 milyonun \%35'ini Y Kuşağı, yani 1980-1999 arası doğanlar oluşturmaktadır. 2025 yılında işgücünün yüzde 6075'inin Y Kuşağı çalışanı olacağı tahmin edilmektedir. Ayrıca 10 yıl içerisinde iş hayatının kuralları, Y Kuşağının özelliklerine ve beklentilerine göre yeniden şekillenecektir (Sözer, 2014). \%35' lik bir oranla çalışma hayatında olan Y Kuşağı iş dünyasında şimdiden bazı değişimlerin yaşanmasını sağlamıştır (Çoban, 2006; URL3). Örneğin Y Kuşağının iş dünyasına girmesiyle çalışanların kariyer ilerlemesi herkesçe bilinen kriterlere göre şeffaf bir değerlendirmeyle yapılmaya başlanmıştır ("Kariyer Planlarını", 2014). Şirketler çalışanlarına işyerlerinde sağlıklı beslenme, spor, masaj ve manikür hizmetleri sağlayarak, hem onların motivasyon ve mutluluklarını arttırmayı hem de 
özel hayatlarına zaman kazandırmayı hedeflemektedirler (Sözer, 2014). Bunların yanı sıra şirketler $Y$ kuşağının yaşam boyu öğrenme kapsamındaki beklentilerini karşılamak üzere çeşitli eğitim ve seminerler düzenlemektedir. Zaman yönetimi, stresle başa çıkma, temel yönetim becerileri gibi kişisel gelişim ve yönetim eğitimleri bunlar arasında sayılabilir (Sözer, 2014). Özel kurumlar, çalışanların esnek zaman ve evden iş yürütme taleplerine de olumlu bakmaktadır. Yine bazı özel kurumlarda haftanın bir günü çalışanlar işe serbest kıyafetle gelebilmektedir.

Eğitimde başarısını ortaya koymuş ve anketlerde öğretmenleri mutlu olarak açklanan ülkelerin eğitim yapıları incelendiğinde, öğretmenlerin mesleki eğitim desteği aldıkları, okul çapında kararlara yoğun katılabildikleri, haftada 17 saat ders yüklerinin olduğu, sadece üç de bir sayıda öğretmenin idari işlerle meşgul olmak zorunda olduğu görülmüştür.

Yapılan bu araştırmaya katılan öğretmenler, ne özel sektördeki Y Kuşağı çalışanları kadar ne de eğitim de başarısını ispatlamış ülkelerde yaşayan Y Kuşağı meslektaşları kadar söz konusu Y Kuşağının yönetimden talep ettiği düzenlemeleri kendi okullarında göremeseler de yöneticilerine yüksek puanlar vermişler ve onları $X$ ve $Y$ Kuşağı seviyesinde oylamışlardır. Oysaki araştırmada incelenen yöneticiler yaş itibariyle çoğunlukla Baby Boomers Kuşağındandır. Bu durum öğretmenlerin işlerini güvence altına alan bürokratik yapıdan hoşlandıklarını ve okul yönetiminden beklentilerinin düşük olduğunu akla getirmektedir.

Beklentinin düşük olmasının sebebi; kamuoyunda kökleşmiş olan, öğretmenlerin aldıkları ücretin, çalıştıkları saatlere ve bolca tatile göre fazla olduğu kanaati ve bunun sonucu olarak kendilerini değersiz hissetmeleri olabilir. Bir başka neden de öğretmenlerin yetiştikleri ailelerin, düşük sosyoekonomik düzeyleri olabilir. Öğretmen annelerinin büyük çoğunluğu ev kadını, babaları memur, işçi ve serbest meslek sahibidir (Pehlivan, 2008). Düşük sosyoekonomik yapı, beklentileri yüksek Y Kuşağı öğretmen neslinin oluşmasını engellemiş olabilir. Üstelik sosyoekonomik çevreleri onların farklı iş sahalarını gözlemlemelerine olanak vermemiş, dolayısıyla özel sektörün yaşadığı değişimden haberdar olamamış olabilirler.

Araştırmanın sonuçlarına göre eğitim genç ve yaşlı tüm kuşakları birbirine yaklaştıran bir olgudur. Buna göre hem öğretmen hem de yönetici kadrosunun çalışma hayatları boyunca eğitim almalarına fırsat verilmelidir. Yüksek lisans, doktora programlarının yanı sıra öğretmen ve yöneticilerin gelişmek istedikleri alanlarda çevre üniversitelerce sağlanacak kredili dersler eğitimcilere profesyonel eğitim desteği verecektir. Öğretmen ve yöneticileri bu konuda heveslendirmek için atama ve yer değiştirmelerde eğitim notu konmalı, yüzdesi yüksek tutulmalıdır. Eğitim programlarını başarıyla tamamlayan öğretmenlerin maaşları ile ilgili tatmin edici düzenlemeler teşvik edici olacaktır. Eğitime zaman ayırabilmeleri için öğretmenlerin ders yükü hafifletilmelidir. Eğitim ile ilgili tüm yatırımlar tüm paydaşlara (yönetici, öğretmen, öğrenci, yurttaş) kazanç olarak geri dönecektir. Araştırmanın sonuçlarına göre Türkiye'nin farklı bölgelerinde yetişmiş yöneticilerin tutumları arasında fark vardır. Meslek yaşamına başlandıktan sonra devam edilen eğitim, hem kültürel farklılaşmayı ortadan kaldıracak hem de kuşaksal eşitlenmeyi ve uzlaşmayı sağlayacaktır. Bu aşamada şunu da belirtmekte fayda vardır ki kişilerin salt beyinlerine yönelmiş bir eğitim sistemi eksik ve sakat olacaktır. İnsanın duygusal eğitimi de eğitim sisteminde yer almalı ve bu konuda yeni düzenlemelere gidilmelidir. Bu türlü bir eğitim kişilerin kültür eşitlenmesini sağlayacak ve daha çok ortak değerler oluşturacaktır. Kişilerin yetiştikleri kültür sebebiyle diğerleri ile arasında oluşan farklılaşma ve çatışmanın 
böylece önüne geçilebilecektir. Okullarda verilecek duygusal ve akademik eğitimin yerelleştirilmesi de gerekli olacaktır. Zihnen ve bedenen sağlıklı kabul edilen bir insan modeline uygun olarak kişilerin zayıf yönleri kuvvetlendirilecek, kuvvetli yönleri ön plana çıkarılacak, sivri yönleri törpülenecektir. Tüm bunlar yapılırken bireysel farklılıklar korunmalıdır. Burada amaç tek tip bireyler yetiştirmek değildir. Amaç topluma bağlı kendi içerisinde biricikliğini korumuş bireyler yetiştirmektir. Üniversitelerde Eğitim Yönetimi ve Denetimi lisans programları tekrar açılmalı, okullardaki farklı kuşakların yönetimi profesyonel ellere bırakılmalıdır. Bu profesyonel yönetim, davranış özellikleri gittikçe karmaşıklaşan yeni kuşakların entegrasyonunu da sağlayacak, böylece insan kaynağı kaybının önüne geçilecektir. Ayrıca yöneticilerin teknolojik yeterliliklerini artırmaya yönelik eğitimlerinin de ihmal edilmemesi gerekmektedir (Cantürk, 2007). Beaver (1991) tarafından yapılan araştırmada; okul müdürlerinin çok az teknolojik yeterliliğe sahip olduğu, görevinde başarı için bilgisayar yeterliliğinin önemli olduğuna inandıkları, ancak çok az teknoloji eğitimi aldıkları açılanmıştır (akt: Yilmaz, 2005).

Hem öğretmen hem de yöneticiler için şeffaf ve herkesçe kriterleri bilinen bir performans değerlendirme sistemi oluşturulmalıdır. Bu doğru davranışların göz ardı edilmeden onaylanmasını ve ödüllendirilmesini sağlayacaktır (Dökmen, 2007). Uygun kriterler oluşturulduğunda gelecek kuşakların çalışma verimliliğini arttıran yönetim davranışlarının sıklığ 1 da arttırılabilecektir. Ayrıca öğretmenlerin ve öğrencilerin okul çapında kararlara katılımı sağlanmalıdır. Yeni kuşakların örgüte entegrasyonunu sağlamak için tüm üyelerin seçme ve kararlara katılım hakkı en üst düzeyde tutulmalıdır. Özcan ve Şeren (2014) öğretmenlerin ve öğrencilerin genelinin, kararlara düşük seviyede katıldıklarını, yüksek seviyede katılmak istediklerini belirtmişlerdir. Benzer bir çalışmada öğretmenlerin okul yönetimine katılma düzeylerine ilişkin Yılmaz (2004) öğretmenlerin eğitimöğretim ile ilgili kararlara bazen katılırken, yönetimle ilgili kararlara hemen hiç katılmadıkları sonucuna varmıştır. Demir (2001), öğretmenlerin büyük çoğunluğunun okullarında alınan eğitim-öğretim ve yönetim boyutundaki kararlara "hiç" katılmadıklarını tespit etmiştir. Okulda öğretmen ve öğrencilerin kararlara katılımı yüksek düzeyde sağlandığında; pratik ve yerel çözümler oluşturmak için yeni kuşakların beklentilerinin ne olduğu konusundaki bilgiye birinci elden ulaşılmış olacaktır. Tabii bahsi geçen okul örgütleri devlet kurumları olduğu için yerel çözümlerin işleyişinin sağlanabilmesi adına yasalarda düzenleme yapılmalıdır. Hem şeffaf performans değerlendirme sistemi hem de okul çapında kararlara katılım demokratik bir okul ortamının yaratılmasını sağlayacaktır. Bu sayede öğretmen ve öğrencilerin memnuniyet ve mutlulukları arttırılacaktır. Zira günümüzde iş hayatında itibar; karlılık ve başarı kadar çalışanların mutluluğunu da tesis edebilmekten geçmektedir (Mengi, 2015). Yönetimde en popüler akım insana yönelimdir (Mengi, 2015). Yönetim ile ilgili karar ve uygulamalarda insan unsuru ön planda tutulmalıdır. Bunun için yönetmelikler ve özlük hakları tekrar gözden geçirilmelidir.

Okul yönetimlerinin daha çok erkeklerden oluşması, yönetimde kadın öğretmenlerin temsil edilmemesine sebep olmaktadır. Bundan dolayı kadın öğretmenlerin, yönetime karşı memnuniyetleri erkek öğretmenlerden daha azdır. Yönetim kadrolarında kadın yöneticilerin sayısını arttıracak önlemler alınmalı ve pozitif yönde ayrımcılık yapılmalıdır.

Aynı araştırma özel okul yöneticileri üzerinde yenilenerek sonuçları; devlet okulu yöneticileri üzerinde yapılan bu araştırma ile karşılaştırıldığında, okul yönetimi açısından yararlı sonuçlar elde edileceği düşünülmektedir. Okul yöne- 
timi ve mezun öğrencilerin niteliklerini, kuşaklar açısından mercek altına alan başka bir araştırmada elde edilen sonuçlarla çağdaş okulların nitelikleri oluşturulabilir. Öğretmenlerin özel sektördeki yaşıtları ile iş alışkanlıkları kuşaklar perspektifinden karşılaştırılarak, öğretmenler için yeni meslek kriterleri oluşturulabilir.

\section{Kaynakça}

Adıgüzel, O., Batur, Z. ve Ekşili, N. (2014). Kuşakların değişen yüzü ve y kuşağı ile ortaya çıkan yeni çalışma tarzı: mobil yakalılar. Süleyman Demirel Üniversitesi Sosyal Bilimler Enstitüsü Dergisi, 1 (19), 165-182.

Âlimoğlu, S. (2010). Kültürün Postmodern Örgüt Yapılarının Oluşmasında Etkisi. Yayımlanmış yüksek lisans tezi, Sakarya Üniversitesi Sosyal Bilimler Enstitüsü.

Argon, T. ve Özçelik, N. (2008). İlköğretim okulu yöneticilerinin değişimi yönetme yeterlikleri. Mehmet Akif Ersoy Üniversitesi Ĕ̆itim Fakültesi Dergisi, 8 (16), 70-89.

Akdemir, A., Konakay, G., Demirkaya, H., Noyan, A. ve Demir, B. (2013). Y kuşağının kariyer algısı, kariyer değişimi ve liderlik tarzı beklentilerinin araştırılması. Ekonomi ve Yönetim Araştırmaları Dergisi, 2 (2), 11-41.

Aslanargun, E. (2007). Modern eğitim yönetimi anlayışına yönelik eleştiriler ve postmodern eğitim yönetimi. Kuram ve Uygulamada Ĕ̆itim Yönetimi Dergisi, 13 (2), 195-212.

Ayhün, S. (2013). Kuşaklar arasındaki farklılıklar ve örgütsel yansımaları. Ekonomi ve Yönetim Araştırmaları Dergisi, 2 (1), 93-112.

Ayhün, S. (2012). Kültürel Değişimlerin Örgütlerde Kuşaklararası Çatışmalara Etkisinin İncelenmesi: Akademisyenlere Yönelik Bir Araştırma. Yayınlanmamış doktora tezi, Çanakkale Onsekiz Mart Üniversitesi Sosyal Bilimler Enstitüsü.

Balc1, A. (2000). İki binli yıllarda türk milli eğitim sisteminin örgütlenmesi ve yönetimi. Kuram ve Uygulamada Ĕ̆itim Yönetimi Dergisi, 6 (4), 495-508.

Baran, H. (2015). Eğitim Yönetimi, Teftişi, Planlaması ve Ekonomisi Lisansüstü Programının Okul Yöneticisi Yeterlikleri Bă̆lamında İncelenmesi. Yayımlanmış yüksek lisans tezi, Eskişehir Osmangazi Üniversitesi Eğitim Bilimleri Enstitüsü.

Bayraktar, B. B. (2008). 21.yy Bilgi Yöneticisi Özellikleri, Rol ve Becerileri, Yetkinlikleri ve Alışkanlıkları (1. Baskı). İstanbul: Beta Basım Yayım.

Bezirci, S. (2012). Farklı Kuşaklardaki Hemşirelerin Meslekten ve İşten Ayrılma Niyetleri İle İş Doyumlarının Incelenmesi. Yayımlanmış yüksek lisans tezi, Dokuz Eylül Üniversitesi Sağlık Bilimleri Enstitüsü.

Bu Ofiste Yaşam Alanı Var. (21 Aralık 2014). Hürriyet.

Büyükışık, M. (1989). İlköğretim Denetçilerinin Rehberlik Etkinliklerinin Gerçekleştirme Düzeyi. Yayımlanmış yüksek lisans tezi, Hacettepe Üniversitesi Sosyal Bilimler Enstitüsü.

Cantürk, G. (2007). Bilgisayar Teknolojisinin Okul Yönetiminde Kullanımında, Okul Yöneticilerinin Bilgisayar Teknolojisine Karşı Tutumları ile Kullanma Düzeyleri ve Öğretmenlerin Bilgisayar Teknolojisini Kullanma Düzeyi: Antalya İli Örneği. Yayımlanmış yüksek lisans tezi, Akdeniz Üniversitesi Sosyal Bilimler Enstitüsü.

Conger, J. A. (1998, January). How 'gen x' managers Manage. First Quarter, 1. http://www.strategybusiness.com/article/9760?gko=fea27adresinden 07.11.2014 tarihinde erişilmiştir.

Çoban, F. (2006). Milenyum Kuşağı Neleri Değiştirecek?. Capital Dergisi, 6, 60-64. 
Demir, S. (2001). İlköğretim Okullarında Öğretmenlerin Kararlara Katılmalarına İlişkin Yönetici ve Öğretmen Görüşleri (Sakarya İli Örneği). Yayımlanmış yüksek lisans tezi, Sakarya Üniversitesi Sosyal Bilimler Enstitüsü.

Demirkaya, H., Akdemir, A., Karaman, E. ve Atan, Ö. (2015). Kuşakların Yönetim politikası beklentilerinin araştırılması. İşletme Araştırmaları Dergisi, 7 (11), 86-204.

Durmuş, A. E. (2002). Yönetici yaşının liderlik davranışları üzerindeki etkileri: bankacılık sektöründen bir grup yönetici üzerine bir araştırma. Akdeniz İ. İ. B. F. Dergisi, 3, 1-20.

Dökmen, Ü. (2007). Küçük Şeyler. İstanbul: Sistem Yayıncllı.

Ekşili, N., Batur, H. ve Ünal, Z. (2014). İş yaşamında x kuşağ1 yöneticilerin algılama farklılıklarından kaynaklanan performans değerlemeleri üzerine bir araştırma. International Conference in Economics, 3 (5), 104-106.

Etlican, G. (2012). X ve Y Kuşaklarının Online Ĕ̆itim Teknolojilerine Karşı Tutumlarının Karşılaştırılması. Yayımlanmış yüksek lisans tezi. Bahçeşehir Üniversitesi Sosyal Bilimler Enstitüsü.

Gümüşeli, A. İ. (2001). Çağdaş okul müdürünün liderlik alanları. Kuram ve Uygulamada Eğitim Yönetimi Dergisi, 7 (4), 531-548.

Karadal, H. ve Ünal, A. (2003). Yönetici yaşam biçimleri ile yöneticinin etkinliği ve İş tatmini arasındaki ilişki: tekstil, çimento, sigorta ve gıda sektöründe bir araştırma. Erciyes Üniversitesi İktisadi ve İdari Bilimler Dergisi, 20, 39-55.

Kariyer Planlarını Kendileri Yapıyor. (Kasım 2 2014). Hürriyet. s.11.

Keleş, H. N. (2011). Y kuşağı çalışanlarının motivasyon profillerinin belirlenmesine yönelik bir araştırma. Organizasyon ve Yönetim Bilimleri Dergisi, 3 (2), 129-138.

Keleş, H. N. (2013). Girişimcilik eğiliminin kuşak farkına göre incelenmesi. Selçuk Üniversitesi İktisadi ve İdari Bilimler Fakültesi Sosyal ve Ekonomik Araştırmalar Dergisi, 26, 23-43.

Kendisi Y Bakış Açısı X. (Şubat 15 2015). Hürriyet. s.11.

Kuğuoğlu İ. H. (1997). Eğitim Yöneticisinin, Yönetim Süreçlerinde Gösterdikleri Performans Bakımından Üstleri ve Astlarınca Değerlendirilmesi. Yayımlanmış doktora tezi, Gazi Üniversitesi Sosyal Bilimler Enstitüsü.

Mengi, Z. (11 Ekim 2009). Bb, X, Y ve Z Kuşakları Birbirinden Çoook Farklı. Hürriyet s.14.

Mengi, Z. (15 Şubat 2015). Çalışanı Mutsuz Olan Şirketin İtibarlı Olma Şansı Yoktur. Hürriyet. s.5.

Millî Eğitim Bakanlığı Strateji Geliştirme Başkanlığı.(2014). Milli Eğitim İstatistikleri. Ankara: Milli Eğitim Bakanlığ.

Özcan, E. G. ve Şeren, M. (2014). Ortaöğretim okullarındaki öğrencilerin okul yönetiminin karar verme sürecine katılımları (Beypazarı örneği). Pegem Eğitim ve Öğretim Dergisi, 4 (2), 111-126.

Özçelik, S. (22 Şubat 2015). Kıdemin yerini performans alıyor. Hürriyet. s.6.

Parlayan, M. A. (2003). Yöneticilerin eğitim gereksinmeleri ile demokrafik özelliklerinin ilişkilendirilmesi. Süleyman Demirel Üniversitesi İktisadi ve İdari Bilimler Fakültesi Dergisi, 8 (3), 27-48.

Pehlivan, K. B. (2008). Sınıf öğretmeni adaylarının sosyo-kültürel özellikleri ve öğretmenlik mesleğine yönelik tutumları üzerine bir çalışma. Mersin Üniversitesi Ĕ̆itim Fakültesi Dergisi, 4 (2), .

Saylı, H. (2008). Geleneksel yönetim paradigmasının sınırlayıcı alanlarına karşı post-modern yönetim paradigmasının geliştirici alanları. Afyon Kocatepe Üniversitesi İ̈BF Dergisi, 10 (2), 180-200.

Senbir, H. (2004). Z Son İnsan mı?. (2. Baskı). İstanbul: "O" Kitaplar.

Seçkin, F.S. (2000). Türkiye'nin Kuşak Profili. Capital Dergisi, 12, 100-106.

Sözer, B. Ö. (31 Ağustos 2014 ). Y Kuşağ 1 Ne İster?. Hürriyet. s.5. 
Şişman, M. (1998). Eğitim yönetiminde kuram ve araştırmada alternatif paradigma ve yaklaşımlar. Kuram ve Uygulamada Eğitim Yönetimi Dergisi, 16 (16), 395-422.

Taşlıyan, M., Eyitmiş, A. M. ve Günduğdu, E. (2014). Y kuşağı iş yaşamından ne bekliyor? Kahramanmaraş Sütçü İmam Üniversitesi İktisadi ve İdari Bilimler Fakültesi Dergisi, 4 (2), 19-32.

Türk Dil Kurumu. (2005). Türkçe Sözlük. Ankara: Türk Dil Kurumu.

Toruntay, H. (2011). Takım Rolleri Çalışması: X ve Y Kuşă̆ı Üzerinde Karşılaştırmalı Bir Araştırma. Yayımlanmış yüksek lisans tezi, İstanbul Üniversitesi Sosyal Bilimler Enstitüsü.

Türetgen, İ. Ö., Ünsal, P., ve Telman, N. (2004). Yöneticiler için liderlik özelliklerini ölçen bir ölçek geliştirme. Psikoloji Çalışmaları Dergisi, 24, 25-44.

Twenge, J. M. (2009). Ben Nesli. (Çev. EsraÖztürk). (3.Baskı) İstanbul: Kaknüs Yayınları.

URL1, http://www.dunya.com/kusaklar-x-y-z-diye-ayristi-pazarlamacilarin-kafasi-karisti 151507h.htm adresinden 18.08.2014 adresinden tarihinde erişilmiştir.

URL2,http://www.acikbilim.com/2013/09/dosyalar/nesiller-ayriliyor-x-y-ve-z-nesilleri.html adresinden 20.10.2014 tarihinde erişilmiştir.

URL3,http://www.capital.com.tr/kusaklar-catisiyor-mu-haberler/16337.aspxadresinden 28.08.2014 tarihinde erişilmiştir.

Uzun, E. (2008). Özel ve Devlet Okulu Yöneticilerinin Liderlik Davranışlarının Öğretmen Görüşlerine Göre Karşılaştırılması. Yayımlanmış yüksek lisans tezi. YeditepeÜniversitesi Sosyal Bilimler Enstitüsü.

Yazıcıoğlu, Y. ve Erdoğan, S. (2004). Spss Uygulamalı Bilimsel Araştırma Yöntemleri. Ankara: Detay Yayıncllik.

Yelkikalan, N., ve Altın, E., (2010). Farklı kuşakların yönetimi. Çanakkale Onsekiz Mart Üniversitesi Biga İ̈BF Fakültesi Yönetim Bilimleri Dergisi, 2, 15-17.

Yelkikalan, N., Altın, E., ve Akatay, A., (2010). Yeni girişimcilik modeli ve yeni nesil girişimci profili: internet girişimciliği ve $\mathrm{y}, \mathrm{m}, \mathrm{z}$ kuşağı girişimcisi. Selçuk Üniversitesi IİBF Sosyal ve Ekonomik Araşttrmalar Dergisi, 20, 389-506.

Yılmaz, A. (2005). Eğitim yönetiminde bilgisayarlardan yararlanmanın avantajları ve dezavantajları. Milli Ĕ̆itim Dergisi, 33 (166).

Yılmaz, N. (2004). Orta Öğretim Kurumlarında Görev Yapan Öğretmenlerin Kararlara Katıllm Düzeyleri. Yayımlanmış yüksek lisans tezi. Gazi Üniversitesi Eğitim Bilimleri Enstitüsü.

Yiğit, Z. (2010). X ve Y Kuşaklarının Örgütsel Tutumlar Açısından İncelenmesi ve Bir Örnek Olay. Yayımlanmış yüksek lisans tezi. Bahçeşehir Üniversitesi Sosyal Bilimler Enstitüsü.

Yu, H. C. ve Miller, P. (2005), Leadershipstyle the $x$ generation and baby boomers compared in different cultural contexts'. Leadership and Organization Development Journal, 26 (1), 35-50.

Yüksekbilgili, Z. (2013). Türk tipi y kuşağı. Elektronik Sosyal Bilimler Dergisi, 12 (45), 342-353. 


\section{Extended Summary}

Social events, economic developments, political situations and technology caused massive changes in human attitudes. The humans that lived at the same time and an account of witnessed the same changes, can show similar attitude forms. Group of people that approximately born in same years, same age conditions, an account of similar difficulties to each other, shared the same faces, obligated to similar duties, find voice in generation (Ayhün, 2013; Türk Dil Kurumu (TDK), 2005). People included in the same generations groups; it is observed similar characteristics in various person activities such as eating-drinking, dressing, thinking. Also a person activity management was changed with attitude forms that the generations carry on to business life. Powerful specifications of management theories that dominate to a term is noticed that is affected from managers and workers expectations and behaviors who works at the same term. Different point of views that is forming management theories with changing generations also have formed the school management. Changing management understanding provided the different school identification occur.

Baby Boomers Generation's managers displayed mainly classic and authoritarian manner, more than intended for human, they line up with saving the establishment profits. When making a decision about their organization, they attach more importance to their chief's opinions than the subordinate opinions; they behave to direction that their chiefs want. In this term, control is very hard and intended for finding guilty and punish him. In this terms school was modern school. Modern school is an organization that is status quo and intended for creating one form person. The term when the $\mathrm{X}$ Generation was the manager, system approach has begun to dominant to management understanding. In this understanding, there is no forms and ready prescriptions. The solutions intended for place, time and situation produced from the manager and workers of the organization. Management's inclination to person, being remembered control with guidance together also started in this term. This term school is postmodern school. Individual's sense and thinkings are important from all things in postmodern school. It is emphasized to persons unique and unity characteristics. School manager is the leader of the school and one hand he is guiding the group and the other hand he is managed from the group.

At the term when the Y Generation was worker and starting to be manager contemporary inclinations dominated the management methods. Management started to bear to person, hierarchy was completely crashed. Instead of this, project groups that is intended for the job that will be done, has been started to establish. There is no absolute and unchangeable degree of manager, anymore. Instead of this, the subject is that someone who has the more experience and the ability about the job that will be done. It is also added customer pleasure concept as well as workers pleasure concept in the organizations. Control was changed place with guiding, inner inspection came into question. Furthermore, in the name of being objective of inspection, performance evaluation criters formed. Again in this term, workers participating decisions has became the top level. This term school is contemporary school. The expectation for success from the students is at the top in this school. Management, in one hand take all precautions for individual teaching, in the other hand work for being a team with all elements of the school. Contemporary school changes the duties to manager that making teaching leadership, visiting teachers in their classroom, walking through classrooms and corridor, appearing at right time and the right place, maintaining the school general going. Thus it prufies stationery works from the manager's duty and charges him more important missions. In these schools, manager must go out from his room anymore. 
In this study, it is aimed to determine which generation habits of school managers reflect more in the point of management comprehension. According to the literature, when the different generations (Baby Boomers, X Generation and Y Generation) began to work in business community, begin to take mission in management teams, they put forward different working styles and management approaches. When the generations that are close to the present show behaviors close the contemporary theories, older generations show behaviors close to the classic theories. Business community focuses the generations to provide maximum success, implement new regulations with the acquired data. According to the literature, school management wasn't evaluated from the generation's perspective before. Schools are the organizations which is the most generation circulation. With evaluating the school managements was aimed both a different view bring in to the literature and provide data in this direction to the school management. For this purpose, it was put account from teachers and managements views in the point of providing data to this study. Evaluating The Manager's Attitude Scale According to The Generations which is developed by Özden (2013) was used to 438 teachers and 60 managers chosen by probability based sampling from approximately 6500 teacher group (Yazıcıŏlu and Erdoğan, 2004). By dint of the 46 matters questionnaire; theachers evaluated the school Managers, also school managers evaluated themselves. This study was carried out with scan model.

For the explanation of arithmetic average of answered matters that included in The questionnaire, the choice at the triple scale degree, 3 points given for the "I agree" choice, 2 points for the "partially agree", 1 point for the "I don't agree" choice.

It is qualified as:

- 1 point Baby Boomers attitude forms

- 2 point $X$ Generation attitude forms

- 3 point $Y$ Generation attitude forms

The obtained data by means of 498 questionnaires was analyzed by using SPSS 22 (Statistical Package for Social Sciences) program and resolved for the purposes of the study goals. It is determined the Cronbach Alpa Trustworthy coefficient and found 89 for measuring the scale's trustworthy. In the data analysis, descriptive statistical methods (frequency, percentage) were used as well as independent samples t-test, one-way ANOVA. The relation was commentated as meaningful in situation that $P$ value is $<.05$. If we explain the results of the study in the point of variables, we say that the school managers find their management attitudes close to the $Y$ Generation. Also teachers see their manager's attitudes close to the $X$ Generation, sometimes $Y$ Generation. This shows that managers find themselves usually contemporary and intended for person, but the teachers don't think like this every time. It is found difference between the female teachers and male teachers views intended for the gender variable results. Male teachers voted their manager's attitudes close to Y Generation and found them more contemporary and intended from human than the female teachers found. It is determined that the managers seen classic and authoritarian by the teachers, as their age is rising. Education softened the sharp effect of the age, manager whose education level is increasing seen by the teachers as more contemporary and intended for human. Manager's grown up culture variable occurred the difference between the teachers opinions, the most voted managers as Baby Boomers and X generation are from Black Sea Region, the most voted managers as Y Generation are from Inner Anatolia Region and East Anatolia Region. 